\title{
cDNA Microarray Analysis Reveals that Antioxidant and Immune Genes Are Upregulated During Involution of the Bovine Mammary Gland
}

\author{
K. Singh, ${ }^{* 1}$ S. R. Davis, ${ }^{\star 2}$ J. M. Dobson, ${ }^{*}$ A. J. Molenaar, ${ }^{*}$ T. T. Wheeler, ${ }^{*}$ C. G. Prosser, ${ }^{* 3}$ V. C. Farr, ${ }^{*}$ \\ K. Oden, ${ }^{*}$ K. M. Swanson, ${ }^{*}$ C. V. C. Phyn, ${ }^{\star 4}$ D. L. Hyndman, $\dagger$ T. Wilson, $\dagger$ H. V. Henderson, ${ }^{*}$ \\ and K. Stelwagen* \\ *AgResearch Ltd., Ruakura Research Centre, PB 3123, Hamilton, New Zealand \\ †AgResearch Molecular Biology Unit, University of Otago, Dunedin, New Zealand
}

\begin{abstract}
We have used cDNA microarray analysis to identify genes that play a role in bovine mammary involution. Involution was induced by termination of milking, and alveolar tissue was collected from 48 nonpregnant Friesian cows in mid lactation sacrificed at $0,6,12$, $18,24,36,72$, and $192 \mathrm{~h}(\mathrm{n}=6$ /group $)$ postmilking. The most highly upregulated genes were those associated with oxidative stress. Quantitative real-time reversetranscription PCR analysis confirmed that mRNA expression of spermidine/spermine $N^{1}$-acetyltransferase was increased by $24 \mathrm{~h}$, superoxide dismutase 2 and metallothionein $1 \mathrm{~A}$ by $36 \mathrm{~h}$, and glutathione peroxidase by $72 \mathrm{~h}$ postmilking. The mRNA expression of the host defense proteins lactoferrin and lingual antimicrobial peptide were increased by $192 \mathrm{~h}$ postmilking. A dramatic increase in the protein expression of lactoferrin by $192 \mathrm{~h}$ postmilking was also detected by Western analysis. Decreased mRNA expression of the milk protein genes $\alpha_{\mathrm{S} 1^{-}}, \beta$-, and $\kappa$-casein, and $\alpha$-lactalbumin were early events in the process of involution occurring within 24 to $36 \mathrm{~h}$ postmilking, whereas $\beta$-lactoglobulin mRNA was decreased by $192 \mathrm{~h}$ postmilking. Decreases in $\alpha$-lactalbumin and $\beta$-lactoglobulin protein levels in alveolar tissue occurred by 24 and $192 \mathrm{~h}$ postmilking, respectively, and the cell survival factors $\beta 1$-integrin and focal adhesion kinase were decreased by 72 and $192 \mathrm{~h}$ postmilking, respectively. The results demonstrate that in the bovine mammary gland, decreased milk protein gene expression and cell survival signal-
\end{abstract}

\footnotetext{
Received November 27, 2007.

Accepted February 27, 2008.

${ }^{1}$ Corresponding author: kuljeet.singh@agresearch.co.nz

${ }^{2}$ Current address: ViaLactia Biosciences (N.Z.) Ltd., Newmarket, Auckland.

${ }^{3}$ Current address: Dairy Goat Co-operative (N.Z.) Ltd., Hamilton, New Zealand.

${ }^{4}$ Current address: DairyNZ Ltd., PB 3221, Hamilton, New Zealand.
}

ing are associated with multiple protective responses to oxidative stress that occur before the induction of immune responses and mammary epithelial cell apoptosis during involution.

Key words: dairy cow, mammary involution, apoptosis, cDNA microarray

\section{INTRODUCTION}

Mammary involution in dairy cows at the end of lactation (i.e., the drying-off period induced by termination of milking) is characterized by a rapid decrease in milk protein gene expression (Goodman and Schanbacher, 1991), apoptosis of mammary epithelial cells (Wilde et al., 1997), and tissue remodeling (Holst et al., 1987). The cessation of milk removal begins the involution process and initially results in distension of the mammary gland, a decline in the rate of milk secretion, an increase in intramammary pressure, a decrease in mammary blood flow, increased tight-junction permeability and lactose efflux, and an inflammatory response (see reviews by Hurley, 1989; Davis et al., 1999). These changes occur within 16 to $18 \mathrm{~h}$ of milk accumulation in the bovine mammary gland followed by complete cessation of milk secretion by approximately $30 \mathrm{~h}$ (Davis et al., 1999) and an increase in mammary epithelial cell apoptosis by 3 to $8 \mathrm{~d}$ postmilking (Wilde et al., 1997; Singh et al., 2005). Lactation can be fully restored after $7 \mathrm{~d}$ without milking (Dalley and Davis, 2006) and partially restored after $11 \mathrm{~d}$ (Noble and Hurley, 1999), implying that significant cell loss through apoptosis does not begin until after $7 \mathrm{~d}$. Similar events occur in the rodent mammary gland during involution, although at a much faster rate (Lund et al., 1996).

Local intramammary signals are responsible for initiating involution in response to milk stasis ( $\mathrm{Li}$ et al., 1997), although the actual trigger of mammary epithelial cell apoptosis at the onset of involution has not yet been identified. Several mechanisms have been 
postulated including autocrine-paracrine homeostatic feedback systems, such as the feedback inhibitor of lactation (Wilde et al., 1987), casein-derived phosphopeptides, (Shamay et al., 2002, 2003), and serotonin (Matsuda et al., 2004). Physical distension of the mammary gland has also been postulated as a key trigger of cessation of milk secretion (Fleet and Peaker, 1978) and increased apoptosis because of a change in shape of mammary epithelial cells from milk accumulation (Topper and Freeman, 1980; Marti et al., 1999).

In rodents there are many different genes that are switched on or off in response to milk stasis (Master et al., 2002; Clarkson et al., 2003; Stein et al., 2003). The best characterized intracellular signaling pathways activated during mammary gland involution are the transforming growth factor- $\beta 3$ pathway (Nguyen and Pollard, 2000), death receptor nuclear factor $-\kappa \mathrm{B}$ pathways (Clarkson et al., 2000; Baxter et al., 2006), and the leukemia inhibitory factor-signal transducer and activator of transcription (STAT)3 pathway (Chapman et al., 1999; Kritikou et al., 2003). Immune signals are also activated in response to milk stasis, suggesting a protective response against inflammation in the mammary gland (Clarkson et al., 2003; Stein et al., 2003). In contrast, survival signals are downregulated at the onset of rodent involution. The key mediator of prolactin signaling, STAT5, is rapidly inactivated (Schmitt-Ney et al., 1992; Liu et al., 1996); IGF survival signals are downregulated due to the upregulation of IGF-binding protein 5 (Tonner et al., 1997); and the disruption of cell-extracellular matrix interactions via the integrins results in downregulation of focal adhesion kinase (FAK) during involution (Gilmore et al., 2000; McMahon et al., 2004).

The role of such factors and signaling pathways during bovine mammary involution is still poorly characterized. The aim of this study was to use cDNA microarray analysis to identify genes differentially expressed at the early stages of involution in the bovine mammary gland, thereby improving understanding of the processes and signaling pathways initiating involution in the dairy cow.

\section{MATERIALS AND METHODS}

\section{Animals}

Involution of the bovine mammary gland was induced by abrupt termination of milking in 48 nonpregnant Friesian dairy cows at or close to their peak milk production and before mating in mid lactation (average DIM, $92 \pm 3$ ). The primiparous cows were solely pasture fed, were milked twice daily from parturition, and had an average daily milk yield of $14.3 \pm 0.3 \mathrm{~kg} /$ cow. The average SCC in composite (4 quarters) milk before the termination of milking was $159,000 \pm 20,000$ cells/mL. The animals were slaughtered at the Ruakura abattoir (Hamilton, New Zealand) using standard commercial procedures (electrical stunning followed by exsanguination) at $0,6,12,18,24,36,72$, and 192 $\mathrm{h}(\mathrm{n}=6$ per group) after the last milking. Mammary alveolar tissue (approximately $30 \mathrm{~g}$ ) was collected from the middle of the upper one-third of the gland of a rear quarter of each animal and snap-frozen in liquid nitrogen for subsequent RNA and protein extraction. Animal experimentation was conducted in compliance with the rules and guidelines of the Ruakura Animal Ethics committee.

\section{Generation of Microarrays}

AgResearch has developed a bovine expressed sequence tag (EST) database that incorporates 203,000 EST, derived from more than 50 tissue libraries, which reduced to $\sim 40,000$ contiguous sequences. The 23,280 EST selected for each microarray slide represented 13,522 distinct contiguous sequences, of which 9,499 were represented only once. Of the selected EST, 16,907 matched entries in the SwissProt database (http://www.expasy.ch/sprot/) and these represented 8,625 different contiguous sequences. The 6,373 EST with no SwissProt matches represented 4,897 different contiguous sequences. The methods for amplifying the EST and printing them onto poly-L-lysine-coated microarray slides at the University of Otago Genomics Facility (Dunedin, New Zealand) were described by Baird et al. (2004).

\section{RNA Preparation, Microarray Hybridization, and Image Analysis}

Total RNA was isolated from alveolar tissue using TRIzol (Invitrogen, Carlsbad, CA) and purified using an RNeasy kit (Qiagen, Valencia, CA). The integrity of the RNA was confirmed by denaturing agarose gel electrophoresis and quantified by UV spectrophotometry. First-strand cDNA was synthesized using $25 \mu \mathrm{g}$ of total RNA and subsequently labeled with $\mathrm{Cy} 3$ and Cy5 monoreactive dyes (Amersham Biosciences UK Ltd., Buckinghamshire, UK) using the SuperScript Indirect cDNA Labeling System (Invitrogen) as described previously (Baird et al., 2004). The slides were hybridized with the labeled cDNA using ULTRAhyb (Ambion Inc., Austin, TX) as described previously (Baird et al., 2004).

Two microarray experiments were carried out to identify early changes in gene expression. Experiment 1 compared the very early time points: 6,12 , and 18 h postmilking. There were 6 blocks with 3 different 
cows, each block containing a sample (cow) from the $6-, 12-$, and 18-h time points, giving 6 cows per time point. Pairwise comparisons of the time points at 6 and $12 \mathrm{~h}, 6$ and $18 \mathrm{~h}$, and 12 and $18 \mathrm{~h}$ and their dye reversals were carried out ( $\mathrm{n}=36$ microarray slides). Experiment 2 compared the 6 -h with the 36 -h time point using a daisy-chain design with 6 cows per time point. Each sample from the 6 -h time point was compared with 2 cows from the 36 -h time point such that each cow from the 36 -h time point was compared with 2 cows from the 6 -h time point along with its dye reversal slide, using a total of 24 slides. Hybridized arrays were scanned in a ScanArray 5000 (Packard BioScience, Billerica, MA). The resulting images were analyzed and data generated using GenePix Pro 3.0 software (Axon Instruments, Union City, CA).

The microarray information has been submitted into the National Center for Biotechnology Information (NCBI) Gene Expression Omnibus (GEO) Web site (http://www.ncbi.nlm.nih.gov/projects/geo/query/ acc.cgi). The accession number for the experiment series is GPL1854.

\section{Quantitative Real-Time Reverse-Transcription PCR Analysis}

Relative mRNA levels for $\alpha$-LA, $\beta$-LG, $\alpha_{\mathrm{S} 1}-\mathrm{CN}, \beta$ $\mathrm{CN}, \kappa-\mathrm{CN}$, lactoferrin, lingual antimicrobial peptide (LAP), superoxide dismutase 2 (SOD2), spermidine/ spermine $N^{1}$-acetyltransferase (SSAT), cytosolic selenium-dependent glutathione peroxidase (cGPX), and phospholipid hydroperoxide glutathione peroxidase (PHGPX) were determined by quantitative real-time reverse transcription PCR (qRT-PCR) using SYBR Green I PCR Master Mix (Applied Biosystems, Foster City, CA) as described previously (Singh et al., 2005). Primer sequences and concentrations, product sizes, and conditions are described in Supplementary Table 1, available online at http://jds.fass.org/content/vol91/ issue6/. Metallothionein 1A (MT1A) mRNA levels were determined by cDNA amplification with TaqMan Universal PCR Master Mix (Applied Biosystems) using probe, primers, and conditions as described in Supplementary Table 1 (http://jds.fass.org/content/vol91/ issue6/). Primers were designed as described previously (Singh et al., 2005). $\beta$-Casein and $\kappa$-CN primer sequences were kindly provided by M. Wells (Primary Industries Research, Victoria, Australia). The $\beta$-LG primer sequences were kindly provided by K. Nones (AgResearch). Lactoferrin primer sequences were from Pfaffl et al. (2003). The cGPX and PHGPX primer sequences were kindly provided by P. K. Theil (Danish Institute of Agricultural Sciences, Research Centre Foulum, Denmark). The $\beta$-actin primer sequences for
SYBR Green I PCR were kindly provided by R. Lee (AgResearch). The PCR products were verified by sequencing (Waikato DNA Sequencing Facility, Hamilton, New Zealand). Both $\beta$-actin and ubiquitin were measured by qRT-PCR and were not differentially expressed across the time series (data not shown); thus, these housekeeping genes were a suitable choice for normalization. The threshold cycles generated by realtime RT-PCR were used to quantify the relative abundance of each gene using the relative standard curve method (Applied Biosystems, Sequence Detection System; Chemistry Guide, 2003). The values for each gene were $\log _{10}$-transformed and normalized to either $\beta$ actin or ubiquitin $\log _{10}$-transformed values.

\section{Western Blot Analysis}

Protein was isolated from alveolar tissue by homogenization in a buffer containing $10 \mathrm{~m} M$ HEPES, $\mathrm{pH}$ 7.9, $1.5 \mathrm{~m} M \mathrm{MgCl}, 10 \mathrm{~m} M \mathrm{KCl}$, and protease inhibitors as described previously (McMahon et al., 2004). Protein concentration was determined using the bicinchoninic acid method (Sigma Chemical Co., St. Louis, MO), and either 20 or $40 \mu \mathrm{g}$ of protein was separated on either 7.5 or $18 \%$ Tris-HCl Criterion gels (BioRad Laboratories, Auckland, New Zealand). The proteins were transferred onto nitrocellulose membranes (HybondC extra, Amersham Biosciences UK Ltd.) using the Criterion blotter system (BioRad Laboratories). The membrane was blocked in Tris-buffered saline solution (0.05 $M$ Tris- $\mathrm{HCl}, 0.15 M \mathrm{NaCl}, \mathrm{pH}$ 7.6) containing $0.05 \%$ Tween 20, 0.1\% BSA, and either 1\% PVP-25 or $4 \%$ nonfat milk and then incubated with primary antibodies overnight at $4^{\circ} \mathrm{C}$. The anti- $\alpha$-LA and anti- $\beta$ LG antibodies were used at 1:500,000 dilution (Bethyl Laboratories Inc., Montgomery, TX), and anti- $\beta 1$-integrin and anti-FAK antibodies were used at 1:3,000 and 1:5,000 dilutions, respectively (Santa Cruz Biotechnology, Santa Cruz, CA), and the anti-lactoferrin antibody was used at 1:20,000 dilution (kindly provided by $R$. McLaren, AgResearch). After rinsing in Tris-buffered saline containing $0.05 \%$ Tween 20 , the membrane was exposed to goat-anti-rabbit (Sigma Chemical Company) or anti-chicken secondary antibody conjugated to horseradish peroxidase at 1:10,000 and 1:50,000 dilutions, respectively, for $2 \mathrm{~h}$ at room temperature. The signal was visualized by enhanced chemiluminescence for $5 \mathrm{~min}$ and then exposed to X Omat AR film (Eastman Kodak Company, Rochester, NY). Developed films were scanned and the density of immunoreactive bands determined using a GS-800 densitometer (BioRad Laboratories) and Quantity One software (BioRad Laboratories). 


\section{Statistical Analysis}

Statistical analyses of the microarray experiments were carried out as described by Baird et al. (2004). For each slide, $\log _{2}$ ratios of the background-corrected intensities of each probe were normalized employing a mixed model with spatial autocorrelation REML in the GenStat software package (GenStat, 2004). In experiment 1 , means ( 6 vs. 12 h, 6 vs. 18 h, and 12 vs. $18 \mathrm{~h}$ ) and $\mathrm{SE}$ of the corrected log ratios were calculated for each probe. In experiment 2, means for 6 vs. 36 $\mathrm{h}$ postmilking comparisons were calculated for each probe. The EST were classified into functional groups using a web-based application, DAVID, with the intermediate and high specificity options (Dennis et al., 2003). This application grouped the genes by their biological process using gene ontology organizing principles, thus providing information on the possible role of genes and functional groups of interest during mammary gland involution. If there were multiple EST encoding the same gene, only those genes that had at least one-third of the EST representing them as differentially expressed $(P<0.01, \geq 1$.5-fold for upregulated or $\leq-1.5$-fold for downregulated genes) were listed in Tables 1 and 2 and Supplementary Tables 2 and 3 (http://jds.fass.org/content/vol91/issue6/).

For qRT-PCR analysis, the differences between means were analyzed using ANOVA in the Minitab software package (Minitab Inc., 2003). The means for each group were backtransformed and expressed as the fold change \pm SEM relative to the 6 -h mean. The 6 -h time point was used in preference to the 0 -h time point because $0 \mathrm{~h}$ represents tissue taken after a 12 $\mathrm{h}$ milking interval (i.e., the regular milking interval immediately before the start of the experiment was 12 h), whereas the 6 -h sample was the sample taken after the shortest milking interval. Statistical analysis of Western blot results was carried out using ANOVA on density of immunoreactive bands, and means were expressed as fold changes relative to the 6-h expression of each protein with the SED. Least significant differences identify the means significantly different from each other $\left({ }^{*} P<0.05\right.$, $* * P<0.01$, and $* * * P<$ 0.001).

\section{RESULTS}

Table 1 lists the genes up- and downregulated at 12 and $18 \mathrm{~h}$ postmilking compared with $6 \mathrm{~h}$, and at $18 \mathrm{~h}$ compared with $12 \mathrm{~h}$ postmilking. A threshold of significance in all comparisons for the microarray experiments was chosen at $P<0.01$, with a signed fold change $\geq 1.5$ for upregulated genes or $\leq-1.5$ for downregulated genes. Decreased by 2 -fold means that the expression level has halved (multiplier is $2^{-1}$ or $1 / 2$ ) and thus, the signed fold change in the tables is writen as -2 . At these early time points only a few genes were differentially expressed (i.e., <30), encompassing a variety of functions (Table 1 ). In contrast, at $36 \mathrm{~h}$ postmilking, 732 genes [including 317 EST with no human reference sequence (RefSeq): GenBank accession number] were differentially expressed compared with 6 h postmilking. The complete lists of genes with human RefSeqs that were up- and downregulated at $36 \mathrm{~h}$ compared with $6 \mathrm{~h}$ postmilking are provided in Supplementary Tables 2 and 3 (http://jds.fass.org/content/vol91/issue6/), respectively. The DAVID classification showed that these genes have many different functions (Supplementary Tables 2 and 3; http://jds.fass.org/content/ vol91/issue6/). The genes with the greatest fold changes have functions predominantly related to oxidative stress, immunity and cell survival. The individual genes related to these functions are shown in Table 2. Ingenuity pathway analysis (Ingenuity Systems, version 4.0, Redwood City, CA) confirmed that similar functional groups were highly differentially expressed $36 \mathrm{~h}$ post-milking compared with $6 \mathrm{~h}$ (data not shown).

Genes with functions related to antioxidant activities were among those with the greatest increase in expression. Expression levels of MT1A were increased by almost 7-fold, those of SSAT and MT2A by more than 3 -fold and SOD2 by almost 3 -fold (Table 2). The differential expression of these genes was confirmed by qRT-PCR, which showed that MT1A, SOD2, and SSAT mRNA levels were increased by $6.8-(P<0.01)$, 4.4- $(P<0.001)$, and 3.2 -fold $(P<0.001)$, respectively, by $36 \mathrm{~h}$ postmilking compared with $6 \mathrm{~h}$ (Figure 1A). In fact, SSAT was increased $(P<0.05)$ at $24 \mathrm{~h}$ postmilking by 1.9 -fold. Two different glutathione peroxidases were examined, with cGPX and PHGPX both increasing $(P<0.05) 72 \mathrm{~h}$ postmilking by 2 -fold and 1.6 -fold, respectively (Figure 1B).

Some immune-related genes were also moderately upregulated at $36 \mathrm{~h}$ postmilking compared with $6 \mathrm{~h}$. These included LPS binding protein, CCAAT/enhancer binding protein- $\delta$, and CD6 antigen, which were upregulated by more than 2 -fold (Table 2). Lactoferrin and serum amyloid A3 were among the genes that were upregulated by almost 2 -fold. In addition, the oncostatin receptor and STAT3 were upregulated $36 \mathrm{~h}$ postmilking (Table 2). In contrast to the microarray analysis, qRT-PCR analysis showed that lactoferrin mRNA levels were unchanged at $36 \mathrm{~h}$ postmilking compared with $6 \mathrm{~h}$, although, by $192 \mathrm{~h}$ postmilking, the mRNA levels were increased 4.6 -fold $(P<0.05$, Figure 2A) and protein levels dramatically increased $(P<0.001$, Figure 2B). The mRNA of another key immune-related gene, LAP, was measured by qRT-PCR analysis and 
Table 1. Genes differentially expressed $(P<0.01, \geq 1.5$-fold or $\leq-1.5$-fold) at 12 and $18 \mathrm{~h}$ postmilking compared with $6 \mathrm{~h}$ (mean \pm SEM) and 18 compared with $12 \mathrm{~h}$ postmilking

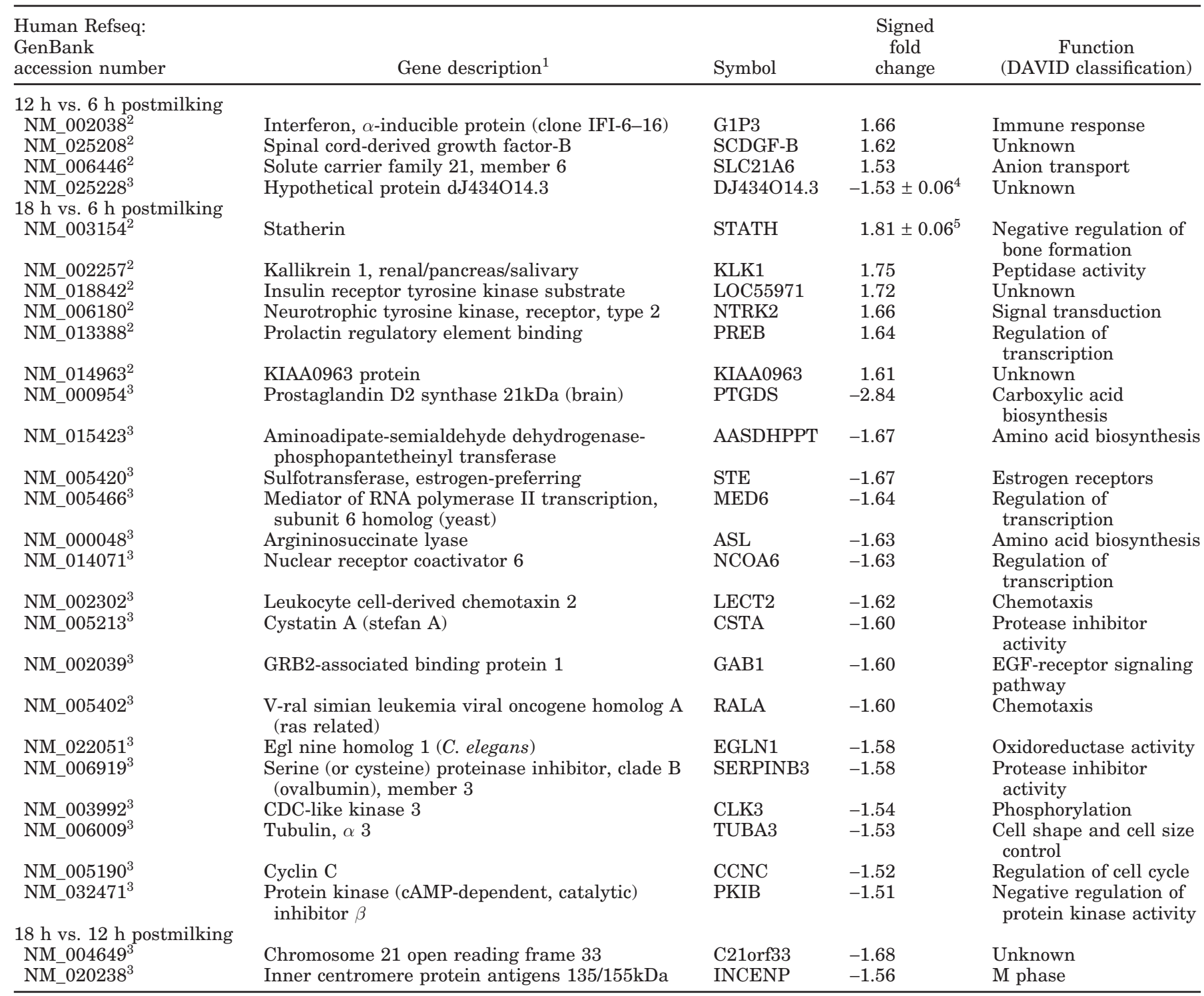

${ }^{1}$ If there were multiple expressed sequence tags (EST) for a gene, only those that have at least one-third differentially expressed are described.

${ }^{2}$ Upregulated genes.

${ }^{3}$ Downregulated genes.

${ }^{4}$ Mean \pm SEM of 2 EST.

${ }^{5}$ Mean \pm SEM of 8 EST.

levels were increased $(P<0.05) 10$-fold by $192 \mathrm{~h}$ postmilking compared with $6 \mathrm{~h}$ (Figure 2A).

The microarray analysis showed that some genes involved in apoptosis during the early phase of involution were differentially expressed at $36 \mathrm{~h}$ postmilking compared with $6 \mathrm{~h}$. The most highly upregulated gene involved in apoptosis was clusterin (2.3-fold), whereas the most highly downregulated gene involved in cell survival was serum/glucocorticoid regulated kinase (3.5-fold, Table 2). Although specific cell survival factors that were differentially expressed in the microarray experiments (Table 2 ) were not evaluated by qRTPCR in the present study, the protein levels of critical factors upstream in cell survival pathways, $\beta 1$-integrin and FAK, were measured. Compared with $6 \mathrm{~h}$ postmilking, $\beta 1$-integrin protein levels tended to be decreased $(P<0.1) 2.3$-fold by $36 \mathrm{~h}$ postmilking and were further decreased by 4.3 - and 5.8 -fold at $72 \mathrm{~h}(P$ 
Table 2. Apoptosis-, antiapoptosis-, immune-, and oxidative stress-related genes (DAVID classifications) differentially expressed $(P<0.01$, $\geq 1.5$-fold or $\leq-1.5$-fold) at $36 \mathrm{~h}$ postmilking compared with $6 \mathrm{~h}$ (mean $\pm \mathrm{SEM}$ )

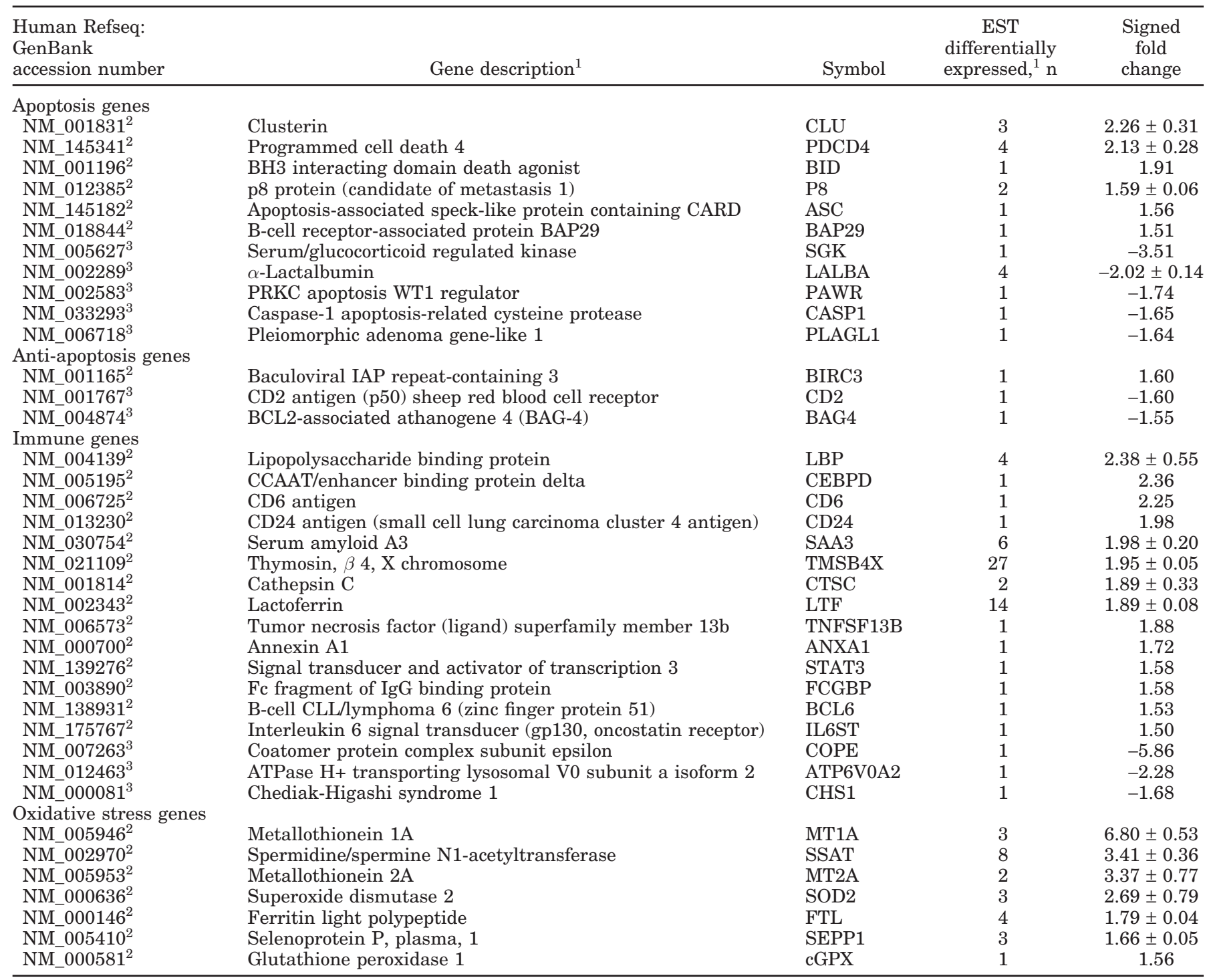

${ }^{1}$ If there were multiple expressed sequence tags (EST) for a gene, only those that have at least one-third differentially expressed are described.

${ }^{2}$ Upregulated genes.

${ }^{3}$ Downregulated genes.

$<0.05)$ and $192 \mathrm{~h}(P<0.01)$ postmilking, respectively (Figure 3). The protein levels of FAK (Figure 3) appeared to follow a similar pattern of expression to that of $\alpha$-LA (Figure 4) during involution.

Microarray analysis showed that the majority of the EST for each milk protein gene were downregulated at $36 \mathrm{~h}$ compared with $6 \mathrm{~h}$ postmilking (Supplementary Table 3; http://jds.fass.org/content/vol91/issue6). The average fold change for the downregulated EST for $\alpha$ LA was 2.0 -fold \pm 0.1 (4 EST), $\alpha_{\mathrm{S} 1}-\mathrm{CN} 1.9$-fold \pm 0.2 (9 EST), $\beta$-CN 1.9-fold \pm 0.1 (7 EST), $\alpha_{\mathrm{S} 2}$-CN 1.8-fold \pm 0.1 (2 EST), and $\kappa$-CN 1.61-fold (1 EST). In comparison,
qRT-PCR analysis showed that the mRNA levels for $\alpha$-LA, $\alpha_{\mathrm{S} 1}-\mathrm{CN}, \beta$-CN, and $\kappa$-CN were downregulated by $11.3-(P<0.01), 8.3-(P<0.01), 4.3-(P<0.01)$, and 2.3 -fold $(P<0.05)$, respectively, at $36 \mathrm{~h}$ postmilking compared with $6 \mathrm{~h}$ (Figure 4). The $\alpha$-LA, $\alpha_{\mathrm{S} 1}-\mathrm{CN}$, and $\kappa$-CN mRNA levels were decreased as early as $24 \mathrm{~h}$ by 3.5- $(P<0.05), 6.6$ - $(P<0.01)$, and 2.4 -fold $(P<0.05)$, respectively, relative to $6 \mathrm{~h}$ postmilking, and expression continued to decrease $(P<0.001)$ until $192 \mathrm{~h}$ after the last milking (Figure 4). Unfortunately, there were no EST on the microarray chip for $\beta$-LG to compare the 2 methods of analysis, but qRT-PCR analysis 


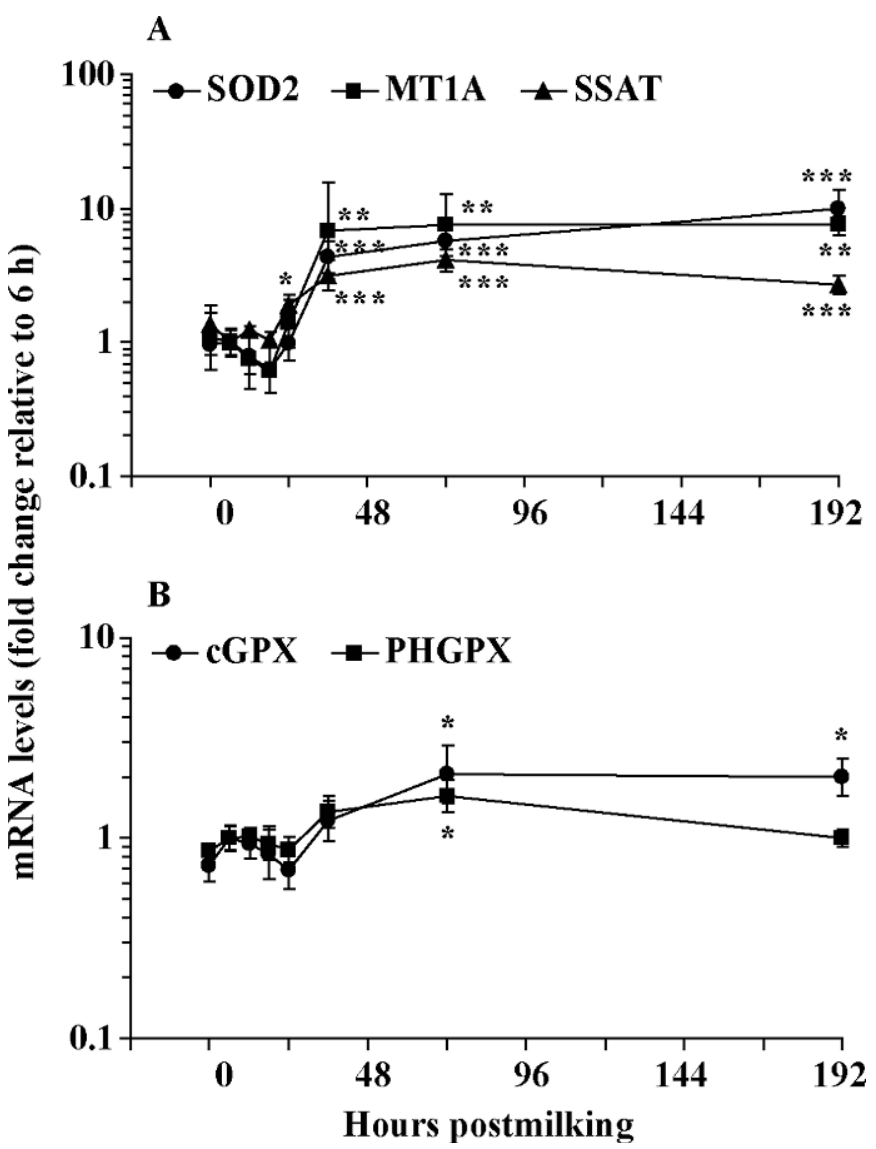

Figure 1. Changes in mRNA levels of oxidative stress factors A) superoxide dismutase 2 (SOD2), metallothionein 1A (MT1A), and spermidine/spermine $N^{1}$-acetyltransferase (SSAT); and B) cytosolic selenium-dependent glutathione peroxidase (cGPX) and phospholipid hydroperoxide glutathione peroxidase (PHGPX) during involution in mammary alveolar tissue of lactating cows ( $\mathrm{n}=6$ per time point). Data are expressed as mean \pm SEM and $P$-values $(* P<0.05$; $* * P<$ $0.01 ; * * * P<0.001)$ are relative to 6 -h time point for respective genes.

showed that $\beta$-LG mRNA declined 2.5 -fold $(P<0.1)$ by $72 \mathrm{~h}$ postmilking and 14.3 -fold $(P<0.001)$ by $192 \mathrm{~h}$ postmilking (Figure 4B). The protein level of $\alpha$-LA immediately postmilking $(0 \mathrm{~h})$ in mammary alveolar tissue was barely detectable, although by $6 \mathrm{~h}$ postmilking it was increased 6.6 -fold $(P<0.05)$. In contrast to the mRNA levels, the $\alpha$-LA protein levels were increased at 12,18 , and $24 \mathrm{~h}$ by $2.2-(P<0.001), 2.6$ - $(P$ $<0.001)$, and 1.7-fold $(P<0.01)$, respectively, compared with $6 \mathrm{~h}$ postmilking (Figure 4C). By $24 \mathrm{~h}$ postmilking, the $\alpha$-LA protein level was decreased by 1.6 -fold $(P<$ $0.01)$ relative to the 18 -h time point, declining to barely detectable levels by $192 \mathrm{~h}$ (Figure $4 \mathrm{C}$ ). The $\beta$-LG protein level was also low immediately after milking (0 h) and increased 2.6 -fold $(P<0.05)$ by $6 \mathrm{~h}$ postmilking (Figure 4C). Thereafter, there was no change in expression, although by $192 \mathrm{~h}$ postmilking $\beta$-LG levels

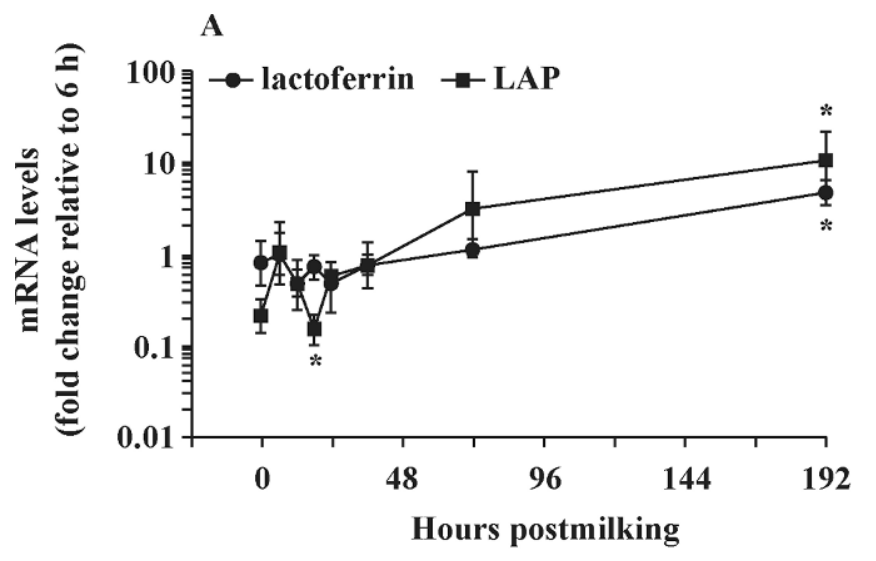

B

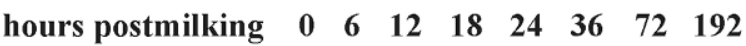

lactoferrin -

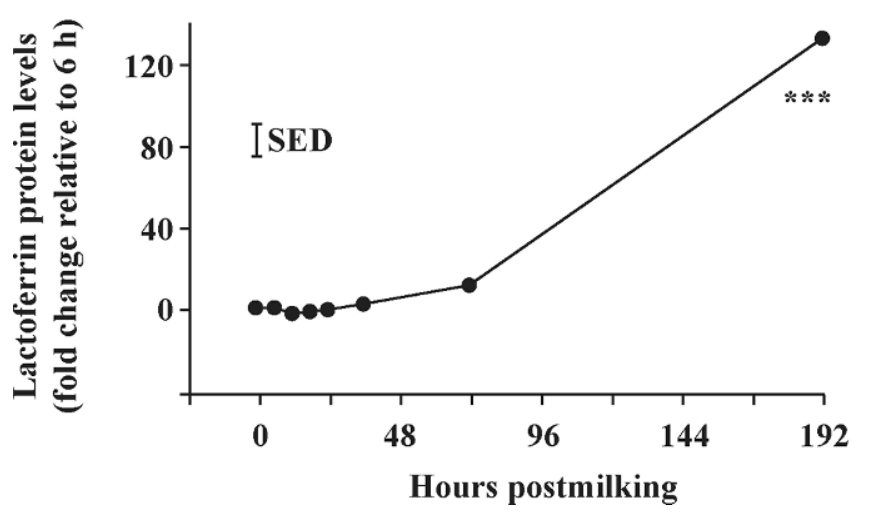

Figure 2. A) Changes in mRNA levels of innate immune factors lactoferrin and lingual antimicrobial peptide (LAP) during involution in mammary alveolar tissue of lactating cows ( $\mathrm{n}=6$ per time point). Data are expressed as mean \pm SEM and $P$-values $(* P<0.05)$ are relative to 6 -h time point for respective genes. $\mathrm{B}$ ) Changes in protein levels of lactoferrin during involution ( $\mathrm{n}=6$ per time point). Western analysis shows a representative sample at each time point $(\mathrm{n}=1)$. Data are expressed as mean fold changes with the SED, and $P$-value $(* * * P<0.001)$ is relative to the 6 -h time point.

tended to be decreased $(P<0.1)$ by 1.9 -fold relative to the 6 -h time point, in agreement with the decrease in mRNA levels at $192 \mathrm{~h}$ compared with $6 \mathrm{~h}$ postmilking.

\section{DISCUSSION}

In contrast to the rodent, much less is known about changes in gene expression and signaling pathways in the involuting bovine mammary gland. The present study has addressed this by using a combination of microarray and qRT-PCR analyses to determine expression patterns of genes and Western blot analysis for proteins. To reduce variability between regions 


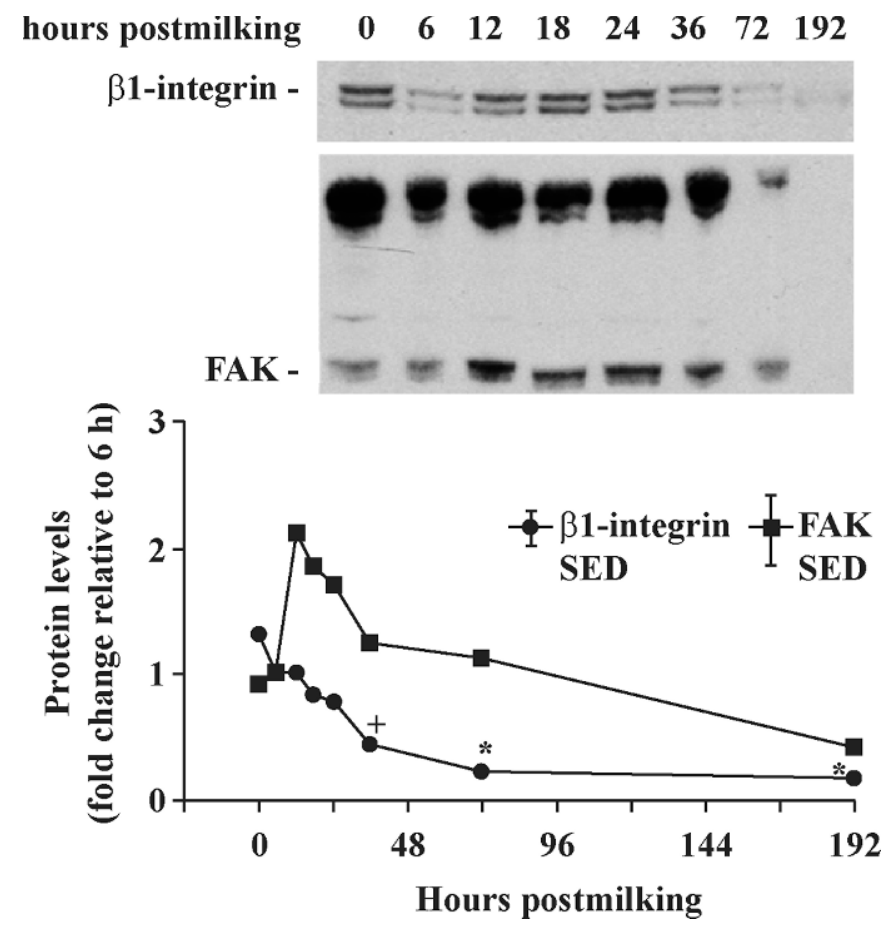

Figure 3. Changes in protein levels of $\beta 1$-integrin and focal adhesion kinase (FAK) during involution in mammary alveolar tissue of lactating cows ( $\mathrm{n}=6$ per time point). Western analysis shows a representative sample at each time point $(\mathrm{n}=1)$. Data are expressed as mean fold changes with the SED, and $P$-values $\left({ }^{+} P<0.1 ; * P<\right.$ $0.05)$ are relative to 6 -h time point for $\beta 1$-integrin.

within the gland, a relatively large amount of mammary alveolar tissue (approximately $30 \mathrm{~g}$ ) from the same region (middle of the upper one-third of the gland) and same gland (rear quarter) of each animal was collected. The microarray results were from 6 cows at each time point. Each slide and its dye reversal compared 2 time points. Involution of the bovine mammary gland, induced by cessation of milking of cows, was associated with up to approximately 8-fold changes in expression of multiple genes at $36 \mathrm{~h}$ postmilking. The level of expression of some genes was different between the cDNA microarray and the more sensitive qRT-PCR analysis, confirming that validation of differentially expressed genes identified by microarray analysis is required (Rajeevan et al., 2001). The genes with the greatest changes in expression as confirmed in both microarray and qRT-PCR analyses can be grouped into 3 main categories based on function-antioxidative, immune, and milk protein genes. The changes in expression of these genes accompany or precede the apparent increase in apoptosis of mammary epithelial cells that occurs by $72 \mathrm{~h}$ postmilking (Singh et al., 2005).

Among the antioxidative genes, SSAT mRNA expression increased significantly by $24 \mathrm{~h}$, SOD2 and

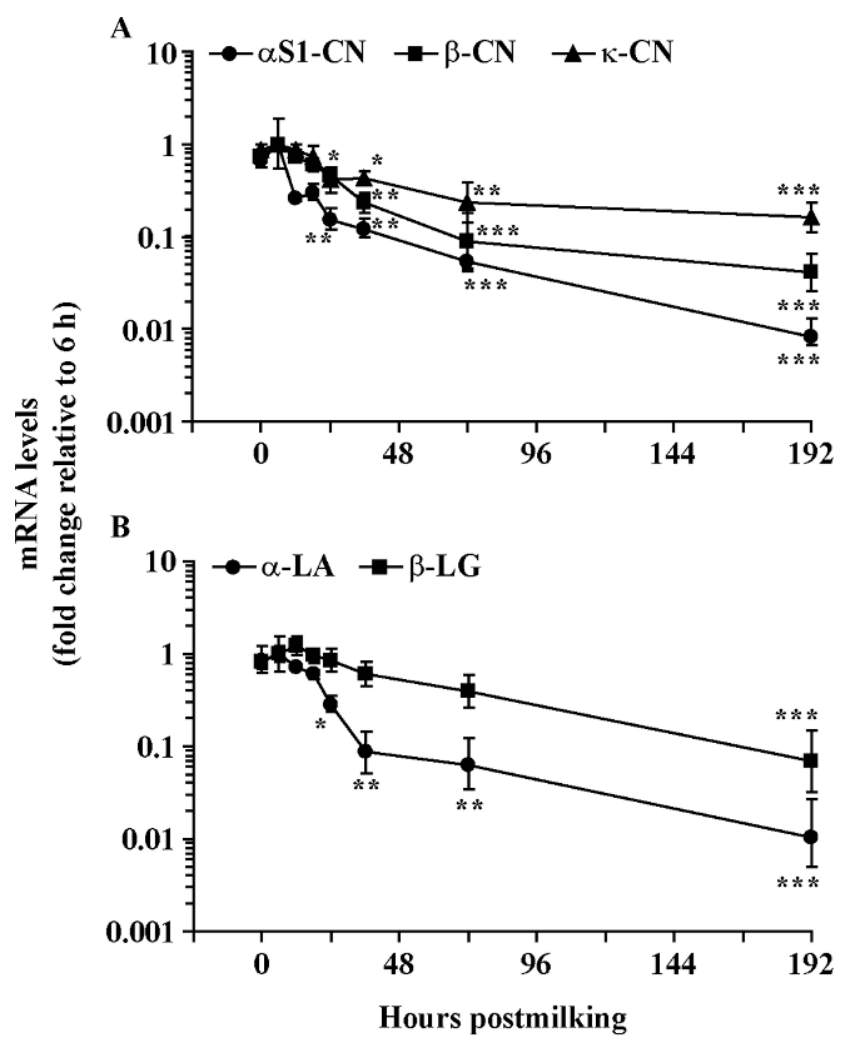

C

$\begin{array}{lllllllll}\text { hours postmilking } & 0 & 6 & 12 & 18 & 24 & 36 & 72 & 192\end{array}$

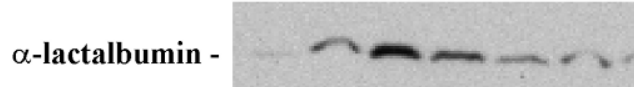

$\beta$-lactoglobulin -

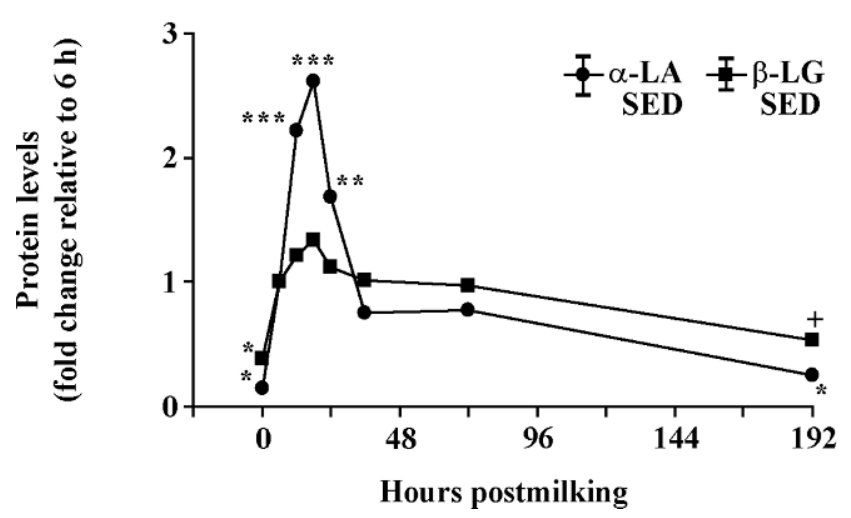

Figure 4. A) Changes in mRNA levels of milk proteins $\alpha_{\mathrm{S} 1}-\mathrm{CN}$, $\beta$-CN, $\kappa$-CN; and B) $\alpha$-LA and $\beta$-LG during involution in mammary alveolar tissue of lactating cows ( $\mathrm{n}=6$ per time point). Data are expressed as mean $\pm \mathrm{SEM}$ and $P$-values $(* P<0.05$; $* * P<0.01$; *** $P$ $<0.001)$ are relative to the 6 -h time point for respective genes. C) Changes in protein levels of $\alpha$-LA and $\beta$-LG during involution ( $\mathrm{n}=$ 6 per time point). Western analysis shows a representative sample at each time point $(n=1)$. Data are expressed as mean fold changes with the SED, and $P$-values $\left({ }^{+} P<0.1 ; * P<0.05 ; * * P<0.01 ; * * * P<\right.$ 0.001 ) are relative to 6 -h time point for respective proteins. 
MT1A mRNA expression increased at $36 \mathrm{~h}$ postmilking, and 2 isoforms of glutathione peroxidase were increased by $72 \mathrm{~h}$ postmilking. The enzyme SOD2 protects cells against the highly reactive radical $\mathrm{O}_{2} \cdot-$ in the mitochondria and converts it into the less-reactive peroxide, which can then be destroyed by catalase or glutathione peroxidase reactions (Majima et al., 1998; Mates and Sanchez-Jimenez, 2000). Metallothionein is important in intracellular zinc homeostasis and protects cells from both hydrogen peroxide- and nitric oxide-induced DNA damage and apoptosis (Chubatsu and Meneghini, 1993; Razavi et al., 2005). Spermidine/ spermine $N^{1}$-acetyltransferase is involved with regulating cytosolic levels of spermidine and spermine and can contribute to oxidative stress and increased apoptosis by this mechanism (Casero and Pegg, 1993). Oxidative stress is caused by an imbalance of reactive oxygen species with cellular antioxidants and can be a trigger for apoptosis (Mates and Sanchez-Jimenez, 2000). Several studies also indicate an increase in production of reactive oxygen species within the involuting bovine mammary gland (Bjorck and Claesson, 1979; Silanikove et al., 2005). The increase in several antioxidant genes in the early stage of mammary gland involution observed in this present study is consistent with an increase in reactive oxygen species, rather than the depletion of antioxidants as the trigger for apoptosis. Further work is required to confirm this and to establish the possible relationship with anoxia in the gland, which is a relatively early event in mammary gland involution (Davis et al., 1999). The microarray analysis showed that clusterin was the most highly upregulated apoptosis-related gene at $36 \mathrm{~h}$ postmilking. This is consistent with findings in rodents, where clusterin is markedly increased during the early phase of mammary gland involution (Marti et al., 1999) and in vitro studies have demonstrated that clusterin is induced by reactive oxygen species (Viard et al., 1999). The present results suggest that oxidative stress may also play an important role in apoptosis and mammary gland involution in the dairy cow.

It has been postulated that the mechanical stretching and shape change of mammary epithelial cells through distension of the mammary epithelium as a result of milk accumulation may cause a decline in milk yield in association with increased tight junction permeability and induction of mechanotransduction signaling pathways (Stelwagen et al., 1997; Davis et al., 1999). Stretching of rodent mammary epithelial cells in vitro resulted in the upregulation of activated STAT3 and the downregulation of $\beta 1$-integrin (Phyn et al., 2006) and cell-extracellular matrix proteins, integrins and FAK, are downregulated at the onset of mammary gland involution (Gilmore et al., 2000; McMahon et al., 2004). The decline in $\beta 1$-integrin and FAK mRNA during involution described previously (Singh et al., 2005) was confirmed in the present study to occur also at the protein level.

In the bovine mammary gland, the involution process is accompanied by increases in innate immune factors such as lactoferrin and immunoglobulins (Oliver and Smith, 1982; Goodman and Schanbacher, 1991). Previous studies indicated increased leucocyte infiltration of the bovine mammary gland by $192 \mathrm{~h}$ postmilking (Singh et al., 2005). The present study has shown that increases in different innate immune factors occur after the increases in antioxidant factors and at the time of leucocyte infiltration. Mammary serum amyloid expression was increased by $72 \mathrm{~h}$ postmilking (K. Singh, unpublished data) and lactoferrin and LAP by $192 \mathrm{~h}$ postmilking. Lactoferrin has previously been shown to be increased by $3 \mathrm{~d}$ postmilking due to local signals (Goodman and Schanbacher, 1991).

Milk protein gene expression decreased relatively rapidly, occurring as early as $24 \mathrm{~h}$ postmilking for $\alpha$ LA and $\alpha_{\mathrm{S} 1}-\mathrm{CN}$ and by $36 \mathrm{~h}$ postmilking for $\beta$ - and $\kappa$ CN. However, $\beta$-LG mRNA and protein levels were unchanged over the same period. Previously, the expression of $\alpha$-LA and the caseins, but not $\beta$-LG, have been shown to be decreased $72 \mathrm{~h}$ following the cessation of milking, although earlier time points were not investigated (Goodman and Schanbacher, 1991). The reduction in milk protein gene expression was slower than that observed in rodents (Travers et al., 1996), where considerable reduction in CN mRNA expression was observed by $24 \mathrm{~h}$ after litter removal. The degree of reduction in both $\alpha$-LA and $\alpha_{\mathrm{S} 1}$-CN mRNA was very variable, consistent with earlier observations by Northern analysis (Molenaar et al., 2004). In a previous study, cows showing the largest reduction in milk protein mRNA content had more apoptotic products and showed more advanced stages of epithelial involution than those with less reduction (Singh et al., 2005). Somewhat surprisingly, the protein concentration of $\alpha$-LA in mammary alveolar tissue did not closely follow mRNA levels. Protein concentrations were greatest at $18 \mathrm{~h}$ postmilking before declining by $24 \mathrm{~h}$ postmilking. These peaks coincide with maximum alveolar engorgement, and hence, stretch of the cells (Singh et al., 2005) and increased tight-junction leakiness (Stelwagen et al., 1997). In turn, these events may be a trigger for the decreased milk protein gene expression associated with early mammary involution (Goodman and Schanbacher, 1991).

\section{CONCLUSIONS}

The microarray analyses described in this study have provided insight to novel mechanisms that are 
involved in the initiation of mammary gland involution in the dairy cow. We propose that multiple mechanisms related to oxidative stress occur following the early loss of milk protein gene expression and cell survival signaling, subsequently resulting in increased mammary epithelial cell apoptosis and involution of the bovine mammary gland. Direct assessment of the presence of reactive oxygen species and their source in the mammary gland is likely to verify a significant role for oxidative stress in the mammary gland involution process.

\section{ACKNOWLEDGMENTS}

The authors gratefully acknowledge the contributions of A. McCulloch and N. Maqbool (AgResearch) for bioinformatic support.

\section{REFERENCES}

Baird, D., P. Johnstone, and T. Wilson. 2004. Normalization of microarray data using a spatial mixed model analysis which includes splines. Bioinformatics 20:3196-3205.

Baxter, F. O., P. J. Came, K. Abell, B. Kedjouar, M. Huth, K. Rajewsky, M. Pasparakis, and C. J. Watson. 2006. IKKbeta/2 induces TWEAK and apoptosis in mammary epithelial cells. Development 133:3485-3494.

Bjorck, L., and O. Claesson. 1979. Xanthine-oxidase as a source of hydrogen-peroxide for the lactoperoxidase system in milk. J. Dairy Sci. 62:1211-1215.

Casero, R. A., Jr., and A. E. Pegg. 1993. Spermidine/spermine N1acetyltransferase-The turning point in polyamine metabolism. FASEB J. 7:653-661.

Chapman, R. S., P. C. Lourenco, E. Tonner, D. J. Flint, S. Selbert, K. Takeda, S. Akira, A. R. Clarke, and C. J. Watson. 1999. Suppression of epithelial apoptosis and delayed mammary gland involution in mice with a conditional knockout of Stat3. Genes Dev. 13:2604-2616.

Chubatsu, L. S., and R. Meneghini. 1993. Metallothionein protects DNA from oxidative damage. Biochem. J. 291:193-198.

Clarkson, R. W., J. L. Heeley, R. Chapman, F. Aillet, R. T. Hay, A. Wyllie, and C. J. Watson. 2000. NF-kappaB inhibits apoptosis in murine mammary epithelia. J. Biol. Chem. 275:12737-12742.

Clarkson, R. W. E., M. T. Wayland, J. Lee, T. Freeman, and C. J. Watson. 2003. Gene expression profiling of mammary gland development reveals putative roles for death receptors and immune mediators in post-lactational regression. Breast Cancer Res. 6:R92-R108.

Dalley, D. E., and S. R. Davis. 2006. Effect of an extended milking interval on recovery of milk yield and somatic cell count in dairy cows. N.Z. Soc. Anim. Prod. 66:241-244.

Davis, S. R., V. C. Farr, and K. Stelwagen. 1999. Regulation of yield loss and milk composition during once-daily milking: A review. Livest. Prod. Sci. 59:77-94.

Dennis, G., Jr., B. T. Sherman, D. A. Hosack, J. Yang, W. Gao, H. C. Lane, and R. A. Lempicki. 2003. DAVID: Database for Annotation, Visualization, and Integrated Discovery. Genome Biol. 4:R60.1-R60.11.

Fleet, I. R., and M. Peaker. 1978. Mammary function and its control at the cessation of lactation in the goat. J. Physiol. 279:491-507.

GenStat. 2004. GenStat for Windows. Release 7. 7th ed. VSN International Ltd., Oxford, UK.

Gilmore, A. P., A. D. Metcalfe, L. H. Romer, and C. H. Streuli. 2000. Integrin-mediated survival signals regulate the apoptotic function of Bax through its conformation and subcellular localization. J. Cell Biol. 149:431-446.
Goodman, R. E., and F. L. Schanbacher. 1991. Bovine lactoferrin mRNA: Sequence, analysis and expression in the mammary gland. Biochem. Biophys. Res. Commun. 180:75-84.

Holst, B. D., W. L. Hurley, and D. R. Nelson. 1987. Involution of the bovine mammary gland: Histological and ultrastructural changes. J. Dairy Sci. 70:935-944.

Hurley, W. L. 1989. Mammary gland function during involution. J. Dairy Sci. 72:1637-1646.

Kritikou, E. A., A. Sharkey, K. Abell, P. J. Came, E. Anderson, R. W. Clarkson, and C. J. Watson. 2003. A dual, non-redundant, role for LIF as a regulator of development and STAT3-mediated cell death in mammary gland. Development 130:3459-3468.

Li, M., X. Liu, G. Robinson, U. Bar-Peled, K.-U. Wagner, W. S. Young, L. Hennighausen, and P. A. Furth. 1997. Mammaryderived signals activate programmed cell death during the first stage of mammary gland involution. Proc. Natl. Acad. Sci. USA 94:3425-3430.

Liu, X., G. W. Robinson, and L. Hennighausen. 1996. Activation of Stat5a and Stat5b by tyrosine phosphorylation is tightly linked to mammary gland differentiation. Mol. Endocrinol. 10:14961506.

Lund, L. R., J. Romer, N. Thomasset, H. Solberg, C. Pyke, M. J. Bissell, K. Dano, and Z. Werb. 1996. Two distinct phases of apoptosis in mammary gland involution: Proteinases-independent and-dependent pathways. Development 122:181-193.

Majima, H. J., T. D. Oberley, K. Furukawa, M. P. Mattson, H. C. Yen, L. I. Szweda, and D. K. S. Clair. 1998. Prevention of mitochondrial injury by manganese superoxide dismutase reveals a primary mechanism for alkaline-induced cell death. J. Biol. Chem. 273:8217-8224.

Marti, A., H. Lazar, P. Ritter, and R. Jaggi. 1999. Transcription factor activities and gene expression during mouse mammary gland involution. J. Mammary Gland Biol. Neoplasia 4:145-152.

Master, S. R., J. L. Hartman, C. M. D'Cruz, S. E. Moody, E. A Keiper, S. I. Ha, J. D. Cox, G. K. Belka, and L. A. Chodosh. 2002. Functional microarray analysis of mammary organogenesis reveals a developmental role in adaptive thermogenesis. Mol Endocrinol. 16:1185-1203.

Mates, J. M., and F. M. Sanchez-Jimenez. 2000. Review: Role of reactive oxygen species in apoptosis: Implications for cancer therapy. Int. J. Biochem. Cell Biol. 32:157-170.

Matsuda, M., T. Imaoka, A. J. Vomachka, G. A. Gudelsky, Z. Hou, M. Mistry, J. P. Bailey, K. M. Nieport, D. J. Walther, M. Bader, and N. D. Horseman. 2004. Serotonin regulates mammary gland development via an autocrine-paracrine loop. Dev. Cell 6:193203.

McMahon, C. D., V. C. Farr, K. Singh, T. T. Wheeler, and S. R. Davis. 2004 . Decreased expression of $\beta 1$-integrin and focal adhesion kinase in epithelial cells may initiate involution of mammary glands. J. Cell. Physiol. 200:318-325.

Minitab Inc. 2003. MINITAB Statistical Software, Release 14 for Windows, State College, PA.

Molenaar, A. J., V. C. Farr, K. E. Oden, T. T. Wheeler, C. D. McMahon, L. L. Good, K. Stelwagen, K. Singh, and S. R. Davis. 2004. Northern analysis of temporal and spatial variation in milk protein expression during early mammary involution in dairy cows. Proc. N. Z. Soc. Anim. Prod. 64:5-7.

Nguyen, A. V., and J. W. Pollard. 2000. Transforming growth factor beta 3 induces cell death during the first stage of mammary gland involution. Development 127:3107-3118.

Noble, M. S., and W. L. Hurley. 1999. Effects of secretion removal on bovine mammary gland function following an extended milk stasis. J. Dairy Sci. 82:1723-1730.

Oliver, S. P., and K. L. Smith. 1982. Bovine mammary involution following intramammary infusion on colchicine and endotoxin at drying off. J. Dairy Sci. 65:801-813.

Pfaffl, M. W., S. L. Wittmann, H. H. Meyer, and R. M. Bruckmaier. 2003. Gene expression of immunologically important factors in blood cells, milk cells, and mammary tissue of cows. J. Dairy Sci. 86:538-545.

Phyn, C., S. Davis, J. Dobson, K. Stelwagen, and K. Singh. 2006. Stretching rodent mammary epithelial cells in vitro initiates 
changes in protein expression. Proc. 8th Int. Workshop BOLFA, Brazil. (Abstr.)

Rajeevan, M. S., S. D. Vernon, N. Taysavang, and E. R. Unger. 2001. Validation of array-based gene expression profiles by real-time (kinetic) RT-PCR. J. Mol. Diagn. 3:26-31.

Razavi, H. M., J. A. Hamilton, and Q. Feng. 2005. Modulation of apoptosis by nitric oxide: Implications in myocardial ischemia and heart failure. Pharmacol. Ther. 106:147-162.

Schmitt-Ney, M., B. Happ, P. Hofer, N. E. Hynes, and B. Groner. 1992. Mammary gland-specific nuclear factor activity is positively regulated by lactogenic hormones and negatively by milk stasis. Mol. Endocrinol. 6:1988-1997.

Shamay, A., F. Shapiro, G. Leitner, and N. Silanikove. 2003. Infusions of casein hydrolyzates into the mammary gland disrupt tight junction integrity and induce involution in cows. J. Dairy Sci. 86:1250-1258.

Shamay, A., F. Shapiro, S. J. Mabjeesh, and N. Silanikove. 2002. Casein-derived phosphopeptides disrupt tight junction integrity, and precipitously dry up milk secretion in goats. Life Sci. 70:2707-2719.

Silanikove, N., F. Shapiro, A. Shamay, and G. Leitner. 2005. Role of xanthine oxidase, lactoperoxidase, and NO in the innate immune system of mammary secretion during active involution in dairy cows: manipulation with casein hydrolyzates. Free Radic. Biol. Med. 38:1139-1151.

Singh, K., J. Dobson, C. Cooper, S. Davis, V. Farr, A. Molenaar, and K. Stelwagen. 2005. Milk accumulation decreases expression of genes involved in extracellular matrix communication and initiates apoptosis in the bovine mammary gland. Livest. Prod. Sci. 98:67-78.

Stein, T., J. S. Morris, C. R. Davies, S. J. Weber-Hall, M.-A. Duffy, V. J. Heath, A. K. Bell, R. K. Ferrier, G. P. Sandilands, and B.
A. Gusterson. 2003. Involution of the mouse mammary gland is associated with an immune cascade and an acute-phase response, involving LBP, CD14 and STAT3. Breast Cancer Res. 6:75-91.

Stelwagen, K., V. C. Farr, H. A. McFadden, C. G. Prosser, and S. R. Davis. 1997. Time-course of milk accumulation-induced opening of mammary tight junctions and blood clearance of milk components. Am. J. Physiol. 273:379-386.

Tonner, E., M. C. Barber, M. T. Travers, A. Logan, and D. J. Flint. 1997. Hormonal control of insulin-like growth factor-binding protein-5 production in the involuting mammary gland of the rat. Endocrinology 138:5101-5107.

Topper, Y. J., and C. S. Freeman. 1980. Multiple hormone interactions in the developmental biology of the mammary gland. Physiol. Rev. 60:1049-1106.

Travers, M. T., M. C. Barber, E. Tonner, L. H. Quarrie, C. J. Wilde, and D. J. Flint. 1996. The role of prolactin and growth hormone in the regulation of casein gene expression and mammary cell survival: Relationships to milk synthesis and secretion. Endocrinology 137:1530-1539.

Viard, I., P. Wehrli, L. Jornot, R. Bullani, J. L. Vechietti, J. A. Schifferli, J. Tschopp, and L. E. French. 1999. Clusterin gene expression mediates resistance to apoptotic cell death induced by heat shock and oxidative stress. J. Invest. Dermatol. 112:290-296.

Wilde, C. J., C. V. P. Addey, P. Li, and D. G. Fernig. 1997. Programmed cell death in bovine mammary tissue during lactation and involution. Exp. Physiol. 82:943-953.

Wilde, C. J., D. T. Calvert, A. Daley, and M. Peaker. 1987. The effect of goat milk fractions on synthesis of milk constituents by rabbit mammary explants and on milk yield in vivo. Evidence for autocrine control of milk secretion. Biochem. J. 242:285-288. 